\title{
INTERAKSI EDUKATIF DOSEN DENGAN MAHASISWA DALAM PEMBANGUNAN KARAKTER DI FAKULTAS ILMU SOSIAL - UNIMED
}

\author{
Oleh : \\ Rohani, Elfayetti, Mbina Pinem, dan Marlinang Sitompul*
}

\begin{abstract}
Abstrak
Penelitian ini bertujuan untuk mengetahui pengaruh interaksi edukatif dosen dengan mahasiswa dalam pembangunan karakter atau budi pekerti mahasiswa melalui kegiatan perkuliahan di FIS Unimed Medan. Selain itu, penelitian ini juga diharapkan dapat menjadi bahan kajian bagi lembaga atau instansi terkait untuk selanjutnya dapat mengambil langkah-langkah konkrit untuk peningkatan kualitas dan intensitas pembinaan karakter atau budi perkerti mahasiswa dalam rangka membangun karakter bangsa Indonesia. Untuk mencapai tujuan penelitian di atas maka dalam penelitian ini digunakan pendekatan diskriptif kualitatif penulis berinteraksi secara aktif dalam proses pengumpulan data. Peneliti akan menggunakan intuisi dan merumuskan pertanyaan-pertanyaan dan melakukan pengamatan secara cermat.

Untuk memahami makna perilaku dosen-dosen dan mahasiswa dalam berinteraksi peneliti akan melibatkan diri secara langsung dalam situasi sosial. Berdasarkan karakteristik pendekatan kualitatif, peneliti akan mengungkapkan makna dibalik suatu fenomena yang terjadi di FIS Unimed Medan khususnya fenomena yang berkaitan dengan interaksi edukatif dosen dengan mahasiswa dalam rangka pembinaan karakter atau budi pekerti mahasiswa.

Hasil akhir dari penelitian ini adalah peningkatan pembangunan karakter mahasiswa dalam hal ini adalah karakter atau budi pekerti mahasiswa melalui interaksi edukatif dosen di dalam proses pembelajaran di Fakultas Ilmu Sosial Unimed. Hasil penelitian ini menujukkan bahwa karakter mahasiswa FIS Unimed dalam perkuliahan telah menunjukkan karakter yang baik hal tersebut terlihat dari indikator religi, toleransi, disiplin, tanggung jawab, peduli, hormat dan jujur.
\end{abstract}

Kata Kunci : Interaksi Edukatif, Karakter atau Budi

\section{A. Pendahuluan}

Pendidikan di Negara manasaja sedang mengkaji kembali perlunya pendidikan moral dan pendidikan karakter atau budi pekerti dibangkitkan kembali. Hal ini bukan hanya dirasakan oleh bangsa dan masyarakat Indonesia, tetapi juga oleh negara- negara maju. Bahkan di negara- negara Industri dimana ikatan moral menjadi semakin longgar, masyarakatnya mulai merasakan perlunya revisi dari pendidikan moral yang pada akhir- akhir ini

\footnotetext{
* Dosen Jurusan Pendidikan Geografi, Fakultas Ilmu Sosial, UNIMED
} 
mulai ditelantarkan,sebagai contoh Negara Amerika Serikat sudah tahun 1990-an memulai pendidikan karakter.Ini disebabkan keprihatinan terhadap meningkatnya kejahatan bunuh diri di kalangan remaja, perceraian, aborsi dan lain-lain.

Hal serupa juga terjadi di Indonesia, berbagai pihak menyuarakan tentang pentingnya pendidikan karakter atau budi pekerti. Pendidikan karakter atau budi pekerti dianggap sebagai salah satu cara penting unrtuk mengatasi kerusakan moral masyarakat yang sudah berada pada tahap sangat memprihatinkan. Pendidikan karakter atau budi pekerti merupakan salah satu indikator dari keberhasilan pendidikan yang diterapkan di Indonesia. Sebab budi pekerti dianjurkan agar selalu diintegrasikan kepada mata pelajaran-mata pelajaran terutama pada Pendidikan Pancasila dan kewarganegaraan (PPKn).

Budi pekerti yang telah terabaikan merupakan awal dari dekadensi moral yang memerlukan pembangunan, di mana seperti ini diharapkan dapat dimulai dari dunia pendidikan melalui dosendosen di kampus. Interaksi antara dosen dan mahasiswa dalam membangun karakter atau budi pekerti tidak dapat terjadi dengan serta merta tanpa adanya kiat-kiat dan metode khusus. Untuk itu diperlukan interaksi yang mendidik yang disebut dengan interaksi edukatif di mana dosen dengan mahasiswa berinterarksi sambil mengimplementasikan karakter atau budi pekerti melalui mata kuliah yang diajarkan, di samping mata kuliah PPKn yang diajarkan pada semsester I itu sendiri. Interaksi edukatif antara dosen dan mahasiswa sangat urgen untuk dilaksanakan mengingat perubahan tingkah laku serta pembentukan karakater mahasiswa tidak terlepas dari tujuan dan hasil pendidikan itu sendiri.

Baik buruknya budi pekerti anak bangsa sangat tergantung kepada keberhasilan pembinaan karakter atau budi pekerti melalui pendidikan karakter atau budi pekerti di kampus-kampus. Sebab, budi pekerti pada umumnya berisi nilai-nilai perilaku manusia yang akan diukur menurut kebaikan dan keburukannya melalui norma yang berlaku di masyarakat, sehingga semua mata kuliah diharapkan dapat mengintegrasikannya dalam setiap proses kegiatan belajar mengajar/ pembelajaran. Hal ini membuktikan betapa urgennya karakter atau budi pekerti dalam membentuk dan membangun karakter manusia Indonesia.

Dalam rangka mewujudkan pembangunan karakter mahasiswa, Unimed semenjak tahun 2008 mengembangkan kurikulum system KBK Blok, yang menuntut terjadi perubahan paradigma pembelajaran yang berpusat kepada mahasiswa. Pembelajaran yang hanya berorientasi kepada pencapaian hard 
skill perlu di kembangkan dan disempurnakan dengan pemberian unsur soft skill, selanjutnya tahun 2011 Unimed memakai kurikulum KBK dengan pembangunan karakter. Implementasi dari kurikulum ini dilakukan melalui integrasi yakni melalui proses pembelajaran yang menunjang terbentuknya karakter atau budi pekerti mahasiswa.

Fakultas Ilmu Sosial misalnya, sebagai salah satu Fakultas yang ada di Universitas Negeri Medan (UNIMED) memerlukan adanya interaksi edukatif antara dosen dan mahasiswa dalam rangka pembangunan karakter atau budi pekerti, karena tanpa adanya interaksi edukatif antara dosen dan mahasiswa, maka segala bentuk pembelajaran akan sia-sia. Sebab FIS UNIMED merupakan salah satu Fakultas yang mahasiswanya heterogen, artinya mahasiswa yang belajar di FIS UNIMED ini adalah campuran dari beberapa suku dan dari beberapa agama yang masing-masing memiliki perbedaan sosial dan budaya.

Dengan mengacu kepada latar belakang masalah, identifikasi masalah dan batasan masalah di atas, maka yang menjadi rumusan masalah dalam penelitian ini adalah: "Bagaimana interaksi edukatif dosen dengan mahasiswa dalam pembangunan karakter atau budi pekerti mahasiswa yang dilakukan di FIS Unimed.”. Untuk lebih mengarahkan permasalahan dapat di uraikan pada beberapa pertanyaan sebagai berikut:

1. Bagaimanakah Interaksi edukatif dosen dengan mahasiswa dalam pembangunan karakter atau budi pekerti mahasiswa melalui kegiatan perkuliahan di FIS Unimed ?

2. Bagaimanakah interaksi edukatif dosen dengan mahasiswa dalam pembangunan karakter atau budi pekerti dalam pergaulan sehari-hari di kampus?

Berdasarkan latar Belakang, Identifikasi masalah dan batasan masalah sebagaimana yang dikemukakan di atas, maka penelitian ini bertujuan untuk:

1. Menjelaskan pengaruh interaksi edukatif dosen dengan mahasiswa dalam pembangunan karakter atau budi pekerti mahasiswa melalui kegiatan perkuliahan di di FIS Unimed Medan.

2. Menjelaskan pengaruh interaksi edukatif dosen dengan mahasiswa dalam pembangunan karakter atau budi pekerti mahasiswa dalam pergaulan sehari-hari di kampus.

\section{B. Metodologi Penelitian}


Penelitian ini dilakukan di Fakultas Ilmu Sosial Univeritas Negeri Medan yang merupakan salah satu Fakultas di Univeritas Negeri Medan. Populasi dalam penelitian ini adalah civitas akademik di FIS Unimed. Penentuan informan (sampel) dilakukan dengan teknik Snow Ball Sampling yang didasari atas pertimbangan-pertimbangan tertentu sesuai dengan keperluan penelitian yang disebut dengan informan kunci (key informan) yaitu Dekan, PD I, Ketua Jurusan, Sekretaris Jurusan, Dosen dan Mahasiswa.

Dalam penelitian ini teknik pengumpulan data dikaitkan dengan langkah-langkah dalam pengumpulan data yang dikemukakan Spradley (1980), Bogdan dan Biklen (1992), Williams (1989), dan Miles \& Huberman (1992), yaitu 1) menentukan situasi sosial, 2) melakukan observasi di lapangan, 3) menentukan teknik pengumpulan, data, 4) menentukan teknik analisis data, 5) merumuskan teknik, dan 6) membuat laporan hasil peneliti.

Dalam penelitian ini teknik analisi data yang digunakan untuk mengolah data yaitu analisis deskriptif kualitatif. Penganalisaan data merupakan langkah yang terpenting dalam penelitian, data yang dikumpulkan perlu diatur untuk mudah diinterpretasikan. Penganalisaan data dilakukan dengan cara teknik analisis data ditawarkan Miles dan Huberman, terjemahan Rohidi (1999), yang terdiri dari: 1) reduksi data, 2) penyajian data, dan 3) kesimpulan.

\section{Hasil Dan Pembahasan}

\section{Religius}

Menurut salah seorang mahasiswa jurusan Pendidikan Antropologi bernama Agus yang ditemui disela - sela makan siangnya pada hari Jumat 15 Juli 2012 kegiatan keagamaan rutin dilaksanakan. Di jurusan Antropologi sendiri, kegiatan kegamaan tergolong rutin dilaksanakan seperti kegiatan lomba. Perlombaan yang dilaksanakan seperti MTQ dan Kaligrafi bagi yang beragama Islam sedangkan untuk yang beragama Kristen perlombaan paduan suara gereja setiap tahun dilaksanakan. Selain perlombaan, kegiatan rutin lainnya yang dilaksanakan adalah acara buka puasa pada bulan Ramadhan. Kegiatan tersebut terselenggara atas kerjasama berbagai pihak khususnya Himpunan Mahasiswa Jurusan, biasanya dana yang digunakan bersumber dari partisipasi Dosen dan Mahasiswa guna mensukseskan acara tersebut. Selain hal tersebut dalam kesempatan saat itu Ali mengemukakan bahwa untuk melaksanakan ibadah shalat bagi mahasiswa yang memeluk 
agama Islam tidaklah sulit, FIS menyediakan ruang musalla di tiap - tiap fakultas sehingga mempermudah pelaksanaan ibadah bagi mahasiswa yang beragama Islam.

Senin 09 Juli 2012 pukul 13.45 wib seusai istirahat makan siang, Ibu Nurjanah selaku ketua jurusan pendidikan Antropoli FIS UNIMED yang berhasil ditemui di ruang kerja beliau mengungkapkan hal yang sama tentang pembinaan karakter dalam bidang keagamaan. Berikut hasil wawancara yang dilakukan penulis :

Tidak terdapat kesulitan dalam membina karakter mahasiswa di Jurusan Pendidikan Antropologi walaupun dalam proses pembinaan karakter tentu tidak dapat terselesaikan hanya dalam satu periode atau satu semester sebab harus berkelanjutan tanpa batas long education. Dalam bidang keagamaan jurusan Antropologi selalu aktif dalam kegiatan - kegiatan keagamaan seperti mengikutsertakan mahasiswa Antropologi dalam perlombaan yang diadakan FIS maupun Universitas dan peringatan hari besar keagamaan yang diselenggarakan jurusan Antropologi, FIS dan Unimed. Saat kuliah sedang berlangsung, tak jarang saya mempersilahkan mahasiswa yang beragama Islam untuk melaksanakan ibadah shalat dengan catatan bahwa mahasiswa secara bergantian keluar ruangan agar kelas tetap kondusif. Untuk memperlancar kegiatan keagamaan tersebut, jurusan Antropologi telah menyediakan sebuah ruangan yang diperuntukkan sebagai mushalla. Waktu ada acara buka puasa bersama, kami usahakan untuk hadir ditengah - tengah mahasiswa agar mahasiswa merasa dekat dan akrab dengan kami dosen dosennya.

\section{Toleransi}

Sikap toleransi juga dirasakan oleh Ali, mahasiswa jurusan Sejarah angkatan 2010 dalam kesempatan yang sama juga mengungkapkan kepada penulis bahwa :

Ada kegiatan - kegiatan yang diberikan dosen pada jamjam istirahat seperti membantu teman-teman memecahkan masalah. Kebetulan saya aktif pada kegiatan jurusan seperti memasukkan mata pelajaran ke puskom. Meurut saya dosen-dosen selalu membimbing mahasiswa untuk dapat berkomunikasi dengan baik. Dalam keseharian terkadan sering terjadi kesalah pahaman antara saya dan teman-teman lain mengingat memang kami berasal dari latar belakang yang berbeda misalnya perbedaan pendapat 
dengan teman satu kelompok tentang penentuan lokasi penelitian dalam tugas kelompok yang diberikan dosen, tetapi tidak pernah sampai berantam. Tugas-tugas kelompok yang diberikan dosen memang memerlukan kerjasama kelompok sehingga mau tidak mau kami harus kompak. Karena kalau tugas sampai terbengkalai, kami sendiri yang rugi karena nilai tugas akan berkurang jika terlambat mengumpulkan dan terdapat batas keterlambatan yang diberikan oleh bapak / ibu dosen, jika melewati batas pengeumpulan maka tidak akan dinilai.

Apa yang dikatakan oleh Ali didukung oleh pernyataan yang diberikan oleh ketua Jurusan Pendidikan Sejarah yang mengemukakan bahwa :

Sikap toleransi antara mahasiswa di Jurusan menurut saya telah terjalin. Sebab mereka ini kan berasal dari daerah yang berbeda, suku, adat - istiadat, ras dan agama yang berbeda pula. Namun belum pernah saya mendengar ada mahasiswa yang bertengkar hingga berkelahi di Jurusan ini. Berbeda pendapat menurut saya itu biasa dan nampaknya mahasiswa di FIS khususnya mahasiswa Jurusan Pendidikan Sejarah telah memahami hal itu, sehingga dapat dikatakan bahawa sikap toleransi telah terjalin di Jurusan Pendidikan Sejarah. Untuk membina rasa toleransi antara mahasiswa di Jurusan Sejarah dilakukan tugas kelompok yang berguna untuk melatih sikap kerjasama dalam memecahkan masalah. Untuk itu tugas - tugas kelompok akan tetap di berikan tentunya dengan pengembangan - pengembangan yang lebih guna peningkatan mutu dari sikap toleransi dan kerjasama tersebut.

\section{Disiplin}

Pada hari Jum'at 22 Juni 2012 pukul 13.00 wib Ekasa Lubis, mahasiswa jurusan pendidikan PPKN angkatan 2009 yang ditemui selesai shalat zuhur di mushalla jurusan Pendidikan PPKN mengemukakan bahwa :

Dalam penerapan sikap disiplin, dosen - dosen di jurusan PPKn sudah cukup tegas karena kami inikan calon guru PPKn yang sangat berkaitan dengan budi pekerti, jadi disiplin itu sangat penting diterapkan. Peraturan peraturan biasanya ditempel di pintu ruangan kuliah. Mungkin sengaja biar kami selalu ingat. 
Hal senada juga diungkapkan oleh Bapak Liber Siagian selaku dosen di Jurusan Pendidikan PPKn yang juga menjabat sebagai Pembantu Dekan III FIS mengungkapkan bahwa :

Kegiatan pembelajaran di masing-masing jurusan telah mencerminkan interaksi eduatif. Saat mantan Rektor terdahulu yaitu Bapak Prof. Syawal Gultom M. Pd memunculkan tentang karakter, beliau mengemukakan bahwa ujung tombak dari pembentukan karakter mahasiswa adalah prodi dalam artian dosen dan pegawai yang memberikan cerminan yang berkarakter di FIS hal tersebut telah dilakukan dengan baik sehingga diawal semester selalu diadakan rapat tentang pembentukan karakter mahasiswa di FIS. Bapak Liber mengemukakan bahwa cara beliau mengajarkan nilai-nilai karakter adalah dengan beliau atau mahasiswa yang masuk dimata kuliah beliau mempunyai karakter seperti berbicara yang santun, disiplin dan mahasiswa dapat menyadari bahwa mahasiswa merupakan calon guru dan beliau selalu berusaha menjadi teladan sebagai Pembantu Dekan III mendukung kegiatan - kegiatan seperti lomba karya tulis ilmiah, kompetisi sepak bola, festival paduan suara dan gerejawi yang diadakan setiap tahun di UNIMED dll yang jika disadari merupakan kegiatan yang dilakukan di FIS untuk bisa membangun karakter mahasiswa. Saat berdiskusi beliau membagi kelompok secara heterogen hal tersebut bertujuan agar mahasiswa dapat saling menghargai tanpa harus membeda-beda Suku, Ras dan Agama. Menurut beliau, mahasiswa cukup dapat menyampaikan dan menghargai pendapat teman yang lain saat sedang berdiskusi, menyampaikan kata-kata yang santun sehingga tidak menyinggung perasaan mahasiswa lainnya.

\section{Tanggung Jawab}

Sikap tanggung jawab juga dibina di Jurusan Pendidikan Geografi Unimed. Berikut hasil wawancara penulis dengan beberapa mahasiswa Jurusan Pendidikan Geografi mengenai tanggung jawab. Menurut Nurpiana, mahasiswa Jurusan Pendidikan Geografi angkatan 2009 yang ditemui penulis mengemukakan bahwa :

Sikap tanggung jawab di Jurusan terbentuk dari tugas tugas yang diberikan oleh dosen saat diperkuliahan. Biasanya ada tugas individu dan kelompok. Dan sejauh ini rata - rata mahasiswa mematuhi tugas - tugas tersebut 
walaupun ada yang mengumpulkannya terlambat. Selain tugas, sikap tanggung jawab juga diperlukan saan kami meminjam alat - alat laboratorium Jurusan. Alat - alatnya banyak, semuanya boleh dipinjam asal bisa dijaga dengan baik karena alat - alat di Geo tergolong langka dicari di Medan dan kalaupun ada harganya mahal, jadi alatnya jangan sampai hilang atau rusak.

Menurut Ibu Nurmala Berutu M. Pd, dosen Jurusan Pendidikan Geografi, yang juga menjabat sebagai Pembantu Dekan I FIS mengemukakan bahwa :

Di Jurusan Pendidikan Geografi, mahasiswa sudah cukup bertanggung jawab dengan memakai dan menggunakan alat laboratorium fisik Geografi dengan hati - hati dan mengembalikan dengan tepat waktu, mengingat alat - alat tersebut selanjutnya akan digunakan kembali oleh mahasiswa lainnya. Besarnya rasa saling memiliki mahasiswa geografi membuat alat - alat laboratorium dapat digunakan untuk jangka waktu yang lama. Sangat jarang mahasiswa merusak atau bahkan menghilangkan alat - alat laboratorium, jika alat - alat tersebut rusak atau bahkan hilang, sanksi terberat adalah mahasiswa diwajibkan mengganti barang tersebut padahal menurut $\mathrm{Bu}$ Nur alat - alat laboratorium di Jurusan PendidikanGeografi tergolong mahal sebab alat - alat tersebut sulit didapat.

\section{Peduli}

Menurut mahasiswa Jurusan Antropologi bernama Sabda Marbun yang berhasil ditemui penulis mengungkapkan bahwa :

Menurut saya sikap peduli di FIS khususnya Jurusan Antropologi sudah dapat dikatakan baik. Dosen - dosen di Jurusan sangat akrab dengan kami mahasiswa, hal ini membuat kami sangat nyaman untuk bercerita masalah masalah yang sedang kami alami khususnya masalah masalah yang berkaitan dengan kuliah. Sikap kepedulian ini membuat saya dan teman - teman merasa bahwa masalah yang sedang kami hadapi itu menjadi tidak terlalu berat. Pernah saat sedang kuliah ada teman yang sakit, kami semua kawan - kawannya tidak ada yang tahu kalau dia sakit. Ntah bagaimana ceritanya, dosen yang pada waktu itu masuk sama kami menegur kawan kami itu dan menanyakan apakah dia sedang sakit dan ternyata memang 
dia sedang kurang enak badan, kemudian dosen menyuruh teman kami yang punya kereta mengantar dia ke kost nya.

Pernyataan dari mahasiswa - mahasiswa Jurusan Antropologi tersebut senada dengan yang dikatakan oleh Ibu Nurjanah selaku Dosen dan Ketua Jurusan Pendidikan Antropologi. Berikut hasil wawancara penulis dengan beliau :

Sikap kepedulian di Jurusan Pendidikan Antropologi lebih diperlihatkan dari hubungan antara manusia - dengan manusia. Dalam pembinaan karakter peduli, kepekaan atas lingkungan sekitar atau pergaulan perlu dilatih. Manusia adalah zoon politicon yang artinya manusia tidak dapat hidup tanpa bntuan dari orang lain, inilah sebabnya kenapa sikap kepedulian harus ditanamkan kepada mahasiswa. Yang pertama sekali saya lakukan adalah saya harus mengenal mahasiswa saya atau minimal saya tahu namanya, dengan begini mahasiswa akan lebih merasa diperdulikan. Saya menegur tindakan - tindakan mahasiswa yang menurut saya kurang pantas sehingga dia merasa bahwa saya perduli kepadanya.

\section{Hormat}

Pada hari Jum'at 22 Juni 2012 pukul 13.00 wib Ekasa Lubis, mahasiswa jurusan pendidikan PPKN angkatan 2009 yang ditemui selesai shalat zuhur di mushalla jurusan Pendidikan PPKN mengemukakan bahwa :

Menurut saya nilai - nilai telah terjalin di Jurusan Pendidikan PPKn, hal itu terlihat dari sikap hormat antara umat beragama. Seperti saat bulan Ramadhan, mahasiswa yang beragama islam melaksanakan ibadah puasa. Alhamdulillahnya teman - temanku yang Kristen menghargai banget, mereka gak makan atau minum di depan kami yang Islam. Bukan hanya itu, kawan - kawan yang Islam dan Kristen juga tidak ribut kalau ada di ruang kuliah yang dekat mushala. Kalau dosen biasanya selalu memperbolehkan kami permisi dari ruangan kelas untuk shalat sebentar.

Hal senada juga diungkapkan oleh Bapak Liber Siagian selaku dosen di Jurusan Pendidikan PPKn yang juga menjabat sebagai Pembantu Dekan III FIS mengungkapkan bahwa :

Saat berdiskusi saya membagi kelompok secara heterogen hal tersebut bertujuan agar mahasiswa dapat saling menghargai tanpa harus membeda - beda Suku, Ras dan Agama. Saya merasa, mahasiswa cukup dapat menyampaikan dan menghormati pendapat teman yang 
lain saat sedang berdiskusi, menyampaikan kata - kata yang santun sehingga tidak menyinggung perasaan mahasiswa lainnya. Saat sedang kuliah, Pak Liber selalu memberikan izin kepada mahasiswa yang beragama islam untuk menjalankan ibadah shalat walupun Pak Liber sendiri bukan pemeluk agama tersebut beliau yakin bahwa saling menghargai dan toleransi antar Menurut Bapak Liber, selama ini kendala yang dihadapi dalam melaksanakan interaksi edukatif dalam pembinaan karakter di FIS relatif kecil seperti mahasiswa sebagai objek yang akan dididik agar berkarakter sehingga bisa santun.

\section{Jujur}

Berikut hasil wawancara penulis dengan Ria, mahasiswa Jurusan Pendidikan Geografi Angkatan 2010 yang berhasil ditemui di depan Kantor Jurusan Pendidikan Geografi pada hari Senin 30 Juni 2012 :

Menurut saya, tidak ada dosen - dosen disini yang melakukan diskriminasi dalam hal pemberian tugas dan penilaian saya rasa dosen - dosen disini dapat dikatakan objektif pemberian nilai secara objektif inilah menurut saya merupakan cerminan sikap jujur dari dosen yang perlu dicontoh.

Menurut Ketua Jurusan Pendidikan Geografi, Bapak Drs. Walbiden Lumbantoruan M. Si mengenai sikap jujur yang ada di Jurusan Pendidikan Geografi yang beliau pimpin. Berikut hasil wawancara penulis dengan beliau :

Saya rasa sikap jujur telah ada dalam diri mahasiswa yang mereka dapat sejak anak - anak hanya saja disini sikap tersebut lebih ditonjolkan mengingat latar belakang mahasiswa di perguruan tinggi sangat beragam. Sikap jujur mahasiswa tersebut terlihat dari adanya sikap saling menyadari akan perbuatan - perbuatan yang mengarah kepada kecurangan - kecurangan antara satu dengan yang lain sehingga kerukunan antara mahasiswa dan juga kami selaku dosen dan fungsionaris FIS dapat berjalan dengan baik. Sikap jujur dalam pembelajaran sendiri secara tersirat terjadi dalam setiap pembelajaran yang kami berikan. Dosen dan mahasiswa di Jurusan Pendidikan Geografi pada umumnya memiliki sikap dan loyalitas yang tinggi terhadap kewajiban mereka. Biasanya di berbagai mata kuliah saat ujian, dosen - dosen membuat jarak tempat duduk agar mahasiswa tidak melakukan 
kecurangan. Dalam hal penilaian menurut saya, dosen dosen di Jrurusan Pendidikan Geografi cukup objektif.

\section{Kesimpulan dan Saran}

\section{Kesimpulan}

Interaksi edukatif dosen dengan mahasiswa dalam pembangunan karakter atau budi pekerti mahasiswa melalui kegiatan perkuliahan di FIS Unimed dapat dikatakan telah berjalan dengan baik. Namun masih ada beberapa hal yang perlu diperbaiki agar FIS kelad dapat menciptakan lulusan - lulusan yang benar benar meiliki karakter dan budi pekerti yang luhur. Pembentukan karakter melalui kegiatan perkuliahan membuat mahasiswa tebiasa melakukan sikap - sikap yang sesuai dengan norma - norma dan nilai - nilai berkarakter yang mencerminkan kopetensi - kopetensi yang harus dimiliki oleh seorang guru.

Interaksi edukatif dosen dengan mahasiswa dalam pembangunan karakter atau budi pekerti dalam pergaulan seharihari di kampus juga berjalan dengan baik. Namun ada beberapa hal yang memang harus terus menerus diperbaiki seperti nilai nilai kejujuran dan tanggung jawab yang masih sangat perlu dibina dalam kehidupan sehari - hari yang tentunya diharapkan akan menjadi kebiasaan dalam kehidupan sehari - hari dalam masyarakat.

\section{Saran}

Untuk dosen hendaknya interaksi edukatif baik di dalam maupun diruang kelas lebih ditingkatkan guna menciptakan karakter - karakter mahasiswa ya baik sehingga dapat menjadi guru - guru yang professional. Dalam hal ini untuk membentuk karakter mahasiswa tentu dosen harus mampu menjadi contoh karakter yang baik guna menumbuhkan sikap dan perilaku yang aik pula oleh mahasiswa.

Untuk mahasiswa hendaknya bersungguh - sungguh dalam mengikuti setiap kegiatanpembelajaran yang diberikan oleh dosen agar tujuan dari pembelajaran selain memperoleh ilmu pengetahuan juga dapat membentuk karakter mahasiswa yang baik setelah menjadi alumni FIS Unimed.

Untuk Fungsionaris FIS hendaknya terus meningkatkan pelayanan yang prima kepada mahasiswa sehingga mahasiswa menjadi lebih nyaman dalam pembelajaran sebab sarana dan prasarana yang baik sangat menunjang kesuksesan pembelajaran dan pembentukan karakter mahasiswa.

\section{Daftar Pustaka}


Anderson, O.W, Krathwohl, D.R. (2001). A Taxonomy for Learning, Teaching, and Assessing. New York: Addison Wesley Longman, Inc

Arends, Richard L, 2008, Learning to Teach. Yogyakarta. Pustaka Pelajar

Arikunto, Suharsimi. (2005). Manajemen Penelitian, Jakarta: Rineka Cipta.

Arikunto, Suharsimi. (2008). Dasar-Dasar Evaluasi Pendidikan, Jakarta: Bumi Aksara

Ausubel, D.P.. (1986). Educational Physichology: A Cognitive View. New York: Holt Rinehart \& Winston

Bigge, Morris L. (1982). Learning Theories For Teachers. New York: Harper \& Row

Dick, W \& Carey, L. (2005). The Systematic Design of Instrustional. New York: Longman

Dimyati. (1994). Belajar dan Pembelajaran, Jakarta: Rineka Cipta

Gerlach, Vernon S \& Ely, Donald P. (1980). Teaching \& Media, A Systematic Approach. New Jersey: Prentice Hall

Kirby, John R. (1984). Cognitif Strategies and Educational Performance. London: Academic Press. Inc

Miarso, Yusufhadi. (2007). Menyemai Benih Teknologi Pendidikan. Jakarta: Kencana

Prawiradilaga, Dewi Salma. (2008). Prinsip Disain Pembelajaran. Jakarta: Kencana

Reigeluth, C. M. (1983). Instructional Design Theory of Models: An Overview of Their Current Status. London: Prentice Hall

Romiszwoski, A.J. (1981). Instructional Design System, Decision Making in Course Planning and Curriculum Design. London: Kogan

Sanjaya, Wina. (2008). Strategi Pembelajaran. Jakarta: Kencana Slavin, R. 1995. Cooperative Learning. Boston : Allyn \& Bacon

Uno, Hamzah B. (2008). Orientasi Baru dalam Psikologi Pembelajaran. Jakarta: Bumi Aksara

Winkel, W.S. (1996). Psikologi Pengajaran. Jakarta: Gramedia Widiasarana Indonesia 
